\title{
Responding to Climate Change by Applying the Techno-Ecological Agriculture Model
}

\author{
Rahmanelli ${ }^{1}$, Ratna Wilis ${ }^{2(*)}$, Sugeng Nugroho ${ }^{3}$, and Afdhal ${ }^{4}$ \\ ${ }^{1}$ Department of Geography, Faculty of Social Sciences, Universitas Negeri Padang, Indonesia \\ ${ }^{2}$ Postgraduate Environmental Study Program, Universitas Negeri Padang, Indonesia \\ ${ }^{3}$ Padang Pariaman Climatology Station, BMKG, Indonesia \\ ${ }^{4}$ Fakultas Ilmu Pendidikan, Universitas Negeri Padang, Indonesia \\ *Corresponding author. Email: ratna_geounp@yahoo.com
}

\begin{abstract}
The specific objective of this study is to apply a techno-ecological agricultural model in order to respond to climate change. An increase in air temperature will have an impact on decreasing crop productivity, especially in annual crops. This condition also affects livestock productivity. Besides that, an increase in air temperature will also increase pests and diseases, both on plants and livestock stars. Changing rainfall patterns and increasing the intensity of extreme climate events cause drought or floods which will have a great potential to reduce productivity and even thwart harvests. This research method includes research, data related to climate is taken from several BMKG offices, and population data can be from BPS Kota Padang, data processing with RClimDex software, namely the Expert Team for Climate Change Detection and Indices (ETCCDMI) to detect and monitor climate change with a main focus on extreme climate events. The implementation of this activity is planned for 2 phases, which is carried out in 2019 which analyzes, (first) To find out the climate change occurring in the city of Padang, (second) Applying the techno-ecological agricultural model in addressing climate change in the city of Padang. The results showed that the average concentrations of $\mathrm{CO} 2$, $\mathrm{CH} 4$, and $\mathrm{N} 2 \mathrm{O}$ measured up to mid-2010 were $381.7 \mathrm{ppm}, 1824.5 \mathrm{ppb}$, and $323 \mathrm{ppb}$. From the picture above it can be seen that the concentrations for these three gases have increased concentrations for $\mathrm{CO} 2$ by $37.3 \%$, $160.6 \%$ for $\mathrm{CH} 4$, and $19.6 \%$ for $\mathrm{N} 2 \mathrm{O}$. Theincrease in COconcentrations 2 measuredcauses an increase in the value of radiative forcing.
\end{abstract}

\section{Keywords: Climate change, a techno-ecological agricultural model}

\section{INTRODUCTION}

In the midst of the non-light risks that must be faced by farmers, a phenomenon of climate change has emerged, the impact of which is also quite large for farmers, especially rice farmers. Global climate change causes a long dry season or excessive rainy season for rainfall with high rainfall intensity. The accumulation of greenhouse gases such as $\mathrm{CO}_{2}$ (Carbon Dioxide), $\mathrm{CH}_{4}$ (Methane), and $\mathrm{N}_{2} \mathrm{O}$ (Dinitrogen Oxide) in the atmosphere causes the retention of solar thermal energy in the atmosphere that should be released back into space, because greenhouse gases have the property of absorbing and then radiates back the sun's energy. In normal conditions, these gases in proportional amounts cause the temperature of the earth's atmosphere to become warm, but if the amount is no longer proportional (increasing), the function of warming the atmosphere becomes excessive, resulting in the temperature of the earth's atmosphere to increase. The increase in air temperature will also have an impact on crop productivity, especially in annual crops. This condition also affects livestock productivity. Besides that, an increase in air temperature will also increase pests and diseases, both on plants and livestock stars. (Guntoro, 2011) 1

Techno-ecological agriculture seeks to integrate the power of ecological agriculture with technologically advanced agriculture, so that a more productive, efficient and quality agricultural model will be formed with less risk as well as being environmentally friendly. Even techno-ecological agriculture that combines cycle production systems (circulation of nutrients and biomass in one chain) with a touch of advanced technology, will be able to lead to "zero waste" or agriculture without waste.

From several studies conducted in the Padang area related to climate change, among others, the results of the Hermon and Wilis study $(2013)^{2}$ stated the impact of climate change and the conversion of forest land and agriculture land into residential land, which will directly lead to a temperature index trend extreme happened in the city of Padang. In Tanah Datar District, there was an increase in surface air temperature, whether average, maximum or minimum air temperatures. Some extreme climate (surface air temperature and rainfall) indices used to detect climate change show signs of such change (Wilis, 
2014) ${ }^{3}$. Climate change is also thought to cause an increase in extreme climates in rain posts located in Das Batang kuranji and Batang Air Cold, especially trends that describe a decrease in the amount of rain such as a trend of decreasing amounts of rainfall (Nugroho and Wilis, $2018)^{4}$. From the description above it is clear how important it is to conduct research on how to respond to climate change by applying a techno-ecological agricultural model. if farmers can apply this technoecological agricultural model, their welfare will increase.

Techno-ecological agriculture seeks to integrate the power of ecological agriculture with technologically advanced agriculture, so that a more productive, efficient and quality agricultural model will be formed with less risk as well as being environmentally friendly. Even techno-ecological agriculture that combines cycle production systems (circulation of nutrients and biomass in one chain) with a touch of advanced technology, will be able to lead to "zero waste" or agriculture without waste. Techno-ecological agriculture is expected to improve the welfare of farmers so that they can survive comfortably as rice producers. An appropriate variety is cultivated, namely varieties that are low in Greenhouse Gas (GHG) emissions, are resistant to inundation or drought, are resistant to certain pests and diseases, and have high productivity. The use of superior varieties is not enough, farmers must integrate their rice business with other commodities that have a functional relationship in the chain of utilization of food substances so that their businesses become more efficient and profitable. For example farmers can integrate rice plants with livestock (cows or sheep) or with fish (mina paddy).

\section{METHOD}

Type of research is quantitative descriptive. This study specifically aims to detect the occurrence of climate changes that occur in the City of Padang and analyze the application of the techno-ecological agricultural model.

\section{Research Data}

To detect climate change in the City of Padang, data on climatological elements is needed, especially the average air temperature , maximum air temperature, minimum air temperature and rainfall have at least 30 years of data continuity. It also uses the concentration of greenhouse gases in the atmosphere, population growth data as additional data to analyze the detection of climate change in the region.

Observational data on climatology elements were sourced from Teluk Bayur Climatology Station. Greenhouse gas concentration data was sourced from Bukit Kototabang Global Atmospheric Monitoring Station. Whereas the population and socioeconomic data of the Padang area were obtained from BPS Kota Padang. In addition to observing air temperature data, reanalysis data is also used.

The reanalysis data used is surface air temperature data at a height of 2 meters from the surface, in the form of global ERA-Interim reanalysis data from the ECMWF (European Center for Medium-Range Weather Forecast), from January 1979 to December 2013, with a spatial resolution of $0.125^{\mathrm{O}} \times 0.125^{\mathrm{O}}$ with multi-dimensional data format (netCDF).

\section{Device(tools)Data processing}

CDO

Operator Data Climate (CDO) is a software developed by Uwe Schulzweida and Luis Kornblueh of the Max Plank Institute forMeteorology,Germany, in 2009 (CDO version 1.4.1). In this study, $\mathrm{CDO}$ software isused to manipulate ERA-Interim data in multi- dimensional format into numerical data.

\section{GrADS}

Grid Analysis and Display System (GrADS), is a software developed by Brian Doty in 1995. In this study the GrADS software is used to extract ERA-Interim data into data points at predetermined coordinates detecting climate change in The city of Padangt needed data on climatological elements, especially rainfall, maximum air temperature, air temperature at least has a data continuity for 30 years.

\section{RESULTS AND DISCUSSION}

\section{Climate Change Detection in Padang City}

Global climate change has an effect on crop and animal productivity. The techno- ecological agricultural model is suggested as an appropriate solution at this time. The buildup of greenhouse gases such as $\mathrm{CO}_{2}$ (Carbon Dioxide), $\mathrm{CH}_{4}$ (Methane), and $\mathrm{N}_{2} \mathrm{O}$ (Dinitrogen Oxide) in the atmosphere causes solar thermal energy to be retained in the atmosphere which should be released again. Because greenhouse gases have the property to absorb and then emit back in the sun's energy. In normal conditions, these gases in proportional amounts cause the temperature of the earth's atmosphere to become warm, but if the amount increases, the function of warming the atmosphere becomes excessive, resulting in the temperature of the earth's atmosphere to increase. The trend of carbon dioxide can be seen in the figure 1 until 5 .

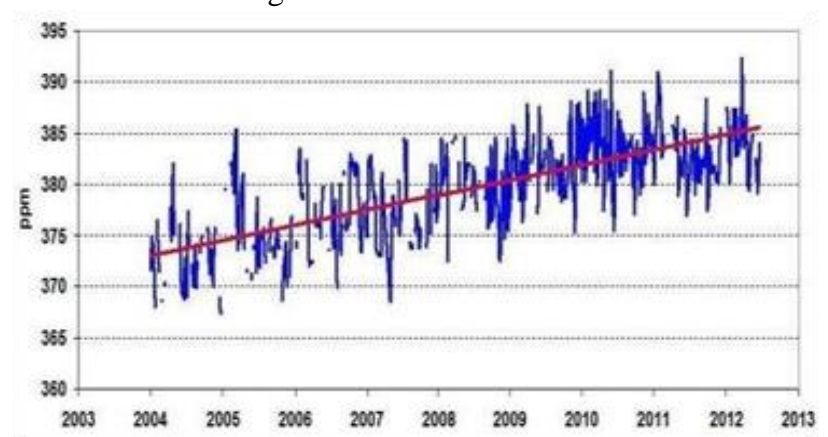

Figure 1. Trend of Carbon Dioxide (COconcentrations for the ${ }_{2}$ )period 2004-2012, the results of monitoring at the Bukit Kototabang Global Atmospheric Monitoring Station (GAW), West Sumatra. 


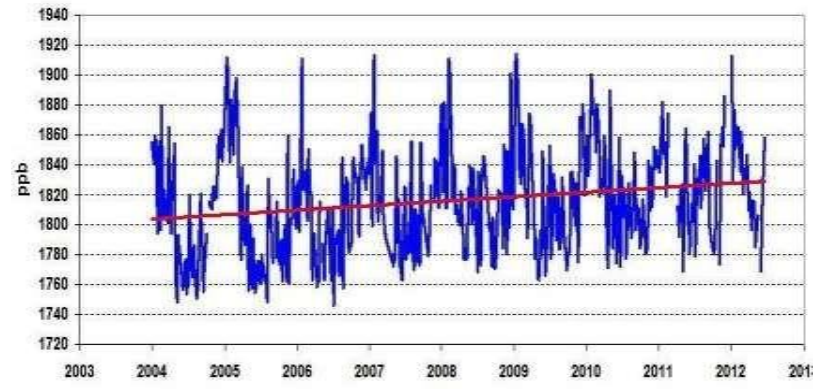

Figure 2. Methan (CHconcentration trend $\mathrm{C}_{4}$ )in the period 2004-2012, the results of monitoring at Bukit Kototabang Global Atmospheric Monitoring Station (GAW), West Sumatra.

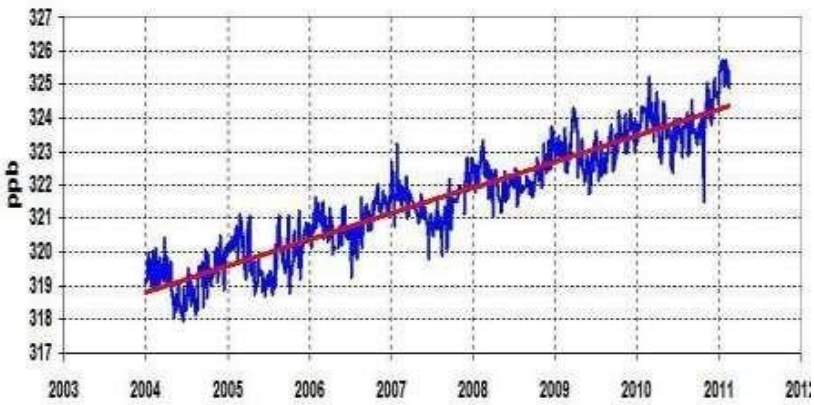

Figure 3. Trend trends in the concentration of nitrous oxide (N2O) for the period 2004-2010,Monitoring Station (GAW), West Sumatra.

The mean concentrations of $\mathrm{CO}_{2}, \mathrm{CH}_{4}$, and $\mathrm{N}_{2} \mathrm{O}$ measured up to mid-2010 were $381.7 \mathrm{ppm}, 1824.5 \mathrm{ppb}$, and $323 \mathrm{ppb}$ respectively. From the picture above it can be seen that the concentrations for these three gases have increased concentrations for $\mathrm{CO}_{2}$ by $37.3 \%, 160.6 \%$ for $\mathrm{CH}_{4}$, and $19.6 \%$ for $\mathrm{N}_{2} \mathrm{O}$. Theincrease in COconcentrations 2 measuredcauses an increase in the value of radiative forcing. The meanvalue of radiative forcing $\mathrm{CO}_{2}$ during measurement was $1.634 \pm 0.04 \mathrm{Wm}^{-}$

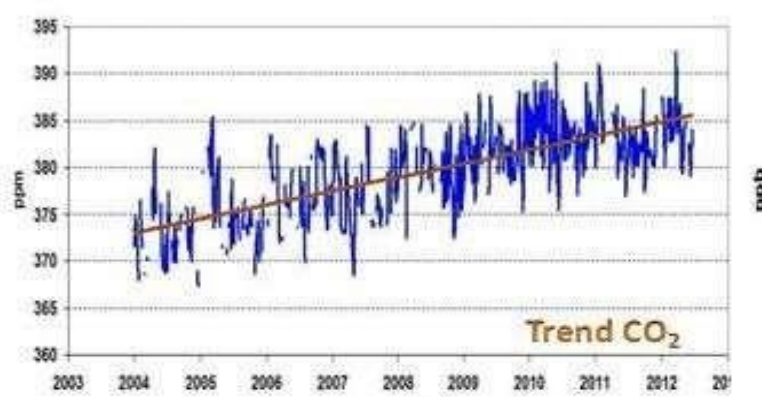

2 , radiative forcing $\mathrm{CH}_{4}$ was $0.509 \pm 0.003 \mathrm{Wm}^{-2}$, and thevalue of radiative forcing $\mathrm{N}_{2} \mathrm{O}$ was $0.168 \pm 0.005 \mathrm{Wm}^{-2}$ (Nahas CN and B. Setiawan, 2009). Trend trends in $\mathrm{CO}_{2}$, $\mathrm{CH}_{4}$, and $\mathrm{N}_{2} \mathrm{O}$ for the period 2004-2010. $\mathrm{CO}_{2}, \mathrm{~N}_{2} \mathrm{O}$, and $\mathrm{NH}_{4}$ are classified as greenhouse gases (GHG) which can naturally absorb heat radiation in the atmosphere, resulting in unstable climate conditions and classified as extreme climates, both temperature and rainfall conditions that are more extreme.

GHG emissions will also increase sharply due to the increased consumption of fossil fuels (BBF) since the industrial revolution in the mid 1980s. Although in the last decade, CHemissions 4 have decreased to 22 million tons / year from 37 million tons / year in the previous decade and Nemissions have ${ }_{2} \mathrm{Oalso}$ decreased slightly from 3.9 to 3.8 million tons / year. COemissions ${ }_{2}$ more than doubled from 1400 million tons / year to 2900 million tons / year. As a result, the temperature of the Earth's atmosphere is now $0.5^{0} \mathrm{C}$ hotter than pre- industrial temperatures. In the long run the Earth's temperature will tend to be hotter than current temperatures. During the past 100 years an increase in the earth's temperature of $0.5 \mathrm{O}_{\mathrm{C}}$ has occurred due to an increase in $\mathrm{CO}_{2}, \mathrm{~N}_{2} \mathrm{O}, \mathrm{SO}_{2}$, and $\mathrm{CH}_{4}$ in the atmosphere. This condition will be worrying because in the next 100 years the concentration of $\mathrm{CO}_{2}$ will double to around $580 \mathrm{ppm}$, of course this change will cause climate change (IPCC, 2001; Hermon, 2010).

Population growth and human activity cause massive land conversion for human needs, especially settlements, many rice fields have changed functions to become housing. Farmers' activities when burning straw also become a cause in adding $\mathrm{CO}_{2}$. This condition causes the GHG trend to also experience a significant increase, both an increase in $\mathrm{CO}_{2}, \mathrm{~N}_{2} \mathrm{O}$, and $\mathrm{NH}_{4}$ in the atmosphere which results in changes in temperature and changes in rain patterns in the city of Padang.

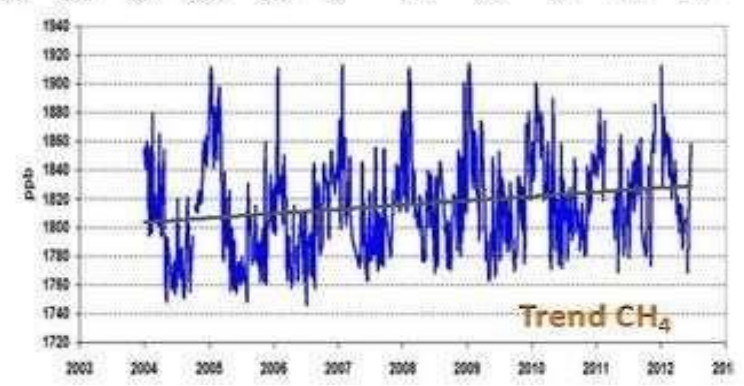

Figure 5.Trend of GHG Change in Padang City 
An increase in $\mathrm{CO}_{2}$ in Padang City due to the conversion of forest land cover into built land which is quite extreme. This condition is also supported by the conversion of bush and garden land cover to built up land, due to the urgent need of the community to build settlements and other built up facilities. As a result, the carbon stock stored on forested land, shrubs and gardens is released (removal) into $\mathrm{CO}_{2}$. Trend $\mathrm{N}_{2} \mathrm{O}$ and $\mathrm{NH}_{4}$ have also increased due to the conversion of paddy fields and fishing and livestock land into built-up land in Padang City.

Along with what Nugroho and Wilis (2018) said, drought conditions at moderate to severe levels will have a significant impact especially in the agriculture sector, clean water supply, and land degradation in the watershed areas because the amount of rain that is relatively small or below normal tends not to be absorbed by the soil but will immediately evaporate into the air. On the other hand, the amount of rainfall that occurs sometimes can no longer replace water reserves that have been lost due to prolonged dry conditions which are thought to be one of the causes due to the decrease in the amount of rain in the watershed area. From the extreme rain indices chosen in the study, among them can clearly describe the decrease in the amount of rain in the watersheds in the city of Padang, especially in the Batang Kuranji watershed where this watershed is the widest watershed and considered changes will occur will have an impact significant for the City of Padang, including the PRCPTOT index; R0 and R50. This has been known as a result of the strong El Nino phenomenon in 1997 which affected the drought in the watershed areas in the city of Padang, especially the Batang Kuranji watershed. Conversely, in 1998 the phenomenon of La Nina occurred strongly, which caused the impact of excessive rain. While in Figure 4c, although it does not clearly illustrate the pattern of a relationship between atmospheric circulation that occurs with this moderate intensity rainfall index, it is clear that it can be seen a decrease in the frequency of rainfall by an amount of $50 \mathrm{~mm}$ or more in one day in the Kuranji watershed area.

Climate change can affect the increase in temperature on the surface of the earth, but can also cause an increase in rainfall in the tropics by $0.2-0.3 \%$. Conversely in some regions of Asia and Africa, the frequency and intensity of drought will increase. Warm conditions have increased since the El Nino- Southern Oscillation (ENSO) in the mid-1970s (Murdiyarso, 2003) · Climate change is directly or indirectly largely caused by human action itself. Forms of action that destroy the composition of the atmosphere include: 1) Greenhouse gas emissions have resulted in thickening of the greenhouse gases (greenhouse gases) so that a lot of heat is trapped and menimbukan global warming. BBF is the largest source of GHG emissions from human activities, 2) Burning coal, oil and natural gas releases billions of tons of $\mathrm{CO}_{2}, \mathrm{CH}_{4}$ and $\mathrm{N}_{2} \mathrm{O}$ into the atmosphere each year and continues to occur until 2019, 3) Agricultural and livestock activities will increasing the concentration of $\mathrm{CH}_{4}$ and $\mathrm{N}_{2} \mathrm{O}$ in large quantities (Hermon, 2010).

\section{CONCLUSIONS}

From the results of the study several conclusions can be drawn including:

Average concentrations of $\mathrm{CO}_{2}, \mathrm{CH}_{4}$, and $\mathrm{N}_{2} \mathrm{O}$ measured up to mid-2010 were $381.7 \mathrm{ppm}, 1824.5 \mathrm{ppb}$, and $323 \mathrm{ppb}$. From the picture above it can be seen that the concentrations for these three gases have increased concentrations for $\mathrm{CO}_{2}$ by $37.3 \%, 160.6 \%$ for $\mathrm{CH}_{4}$, and $19.6 \%$ for $\mathrm{N}_{2} \mathrm{O}$. Theincrease in COconcentrations 2 measuredcauses an increase in the value of radiative forcing. GHG emissions will also increase sharply due to the increased consumption of fossil fuels (BBF) since the industrial revolution in the mid 1980s. Although in the last decade, CHemissions 4 have decreased to 22 million tons / year from 37 million tons / year in the previous decade and Nemissions have ${ }_{2}$ Oalso decreased slightly from 3.9 to

3.8 million tons / year. COemissions 2 more than doubled from 1400 million tons / year to 2900 million tons / year. As a result, the temperature of the Earth's atmosphere is now $0.5^{0} \mathrm{C}$ hotter than pre-industrial temperatures. In the long run the Earth's temperature will tend to be hotter than current temperatures. In the period

100 tahn ago the earth's temperature increase of $0.5^{\circ} \mathrm{C}$ has occurred due to the increase in $\mathrm{CO}_{2} \mathrm{~N}_{2} \mathrm{O}, \mathrm{SO}_{2}$ and $\mathrm{CH}_{4}$ in the atmosphere.

\section{ACKNOWLEDGEMENTS}

This research can be carried out smoothly, because of the help and cooperation of various parties. Therefore, the author would like to thank the Rector of Padang State University and with his permission this research was carried out with the assistance of the UNP PNBP in the 2019 budget year, and the city government of Padang.

\section{REFERENCES}

[1] Guntoro, Suprio. 2011. It's Time to Implement Techno-ecological Agriculture. PT Agromedia Reader.

[2] Jakarta

[3] Heddy, Suwasono, 2010. Agroecosystem of Agricultural Environmental Problems Part One. PT Rajawali Press. Jakarta.

[4] Intergovernmental Panel on Climate Change (IPCC). 2007. A report of the Working Group of the Intergovernmental Panel on Climate Change Summary for Policymakers, Geneva, Intergovernmental Panel on Climate Change.

[5] Nahas, CN and B. Setiawan, 2010. Determination of Radiative Forcing and Annual Greenhouse Gas Index (Aggi) from Carbon Dioxide, Methane, and Nitrous Oxide Measurements Results in Kototabang Hill. Megasains Bulletin, Vol.4

[6] Nugroho, S., Heron, T., and Eddy, S. 2009. Trends of Extreme Rainfall in Padang City, 1970- 2008, Megasains Bulletin, Vol.4. 
[7] Nugroho, S. 2011. Study of Adaptation Simulation on the Level of Thermal Comfort Due to Global Climate Change in Padang City, Scientific Writing of Researchers-LIPI Functional Research, 2010. Widyariset Journal, Vol.14 of 2011, Pusbindiklat-LIPI.

[8] Pudja, IP and Suhardi, B. 2010. The phenomenon of climate change in Indonesia. Meteorology Climatology and Geophysics Agency, Jakarta.

[9] Sastrapradja, SD and Elizabeth AW 2010. Agricultural Biodiversity Guarantees Food Sovereignty. LIPI Press. Jakarta.

[10] Tjasyono, Bayong. 2009. Indonesian Meteorology I Atmospheric Characteristics and Circulation. BMKG. Jakarta.

[11] Tjasyono, Bayong. 2009. Indonesian Meteorology II Clouds and Monsoon Rain. BMKG. Jakarta.

[12]Zhang, $X$ and Yang, F. 2004. RclimDex User Manual (1.0). Climate Research Branch, Enviroment Canada, Downsview, Ontario, Canada.

[13] Determination of Radiative Forcing and Annual Greenhouse Gas Index (Aggi) from Carbon Dioxide, Methane, and Nitrous Oxide Measurement Results in Kototabang Hill 